\title{
Syncretism in Rasolan Tradition among Nahdlatul Ulama Madurese Society
}

\author{
Ellisa M. Sholeh \\ Student of History and Islamic Civilization Master Program, UIN Sunan Kalijaga \\ Yogyakarta \\ ellisasholeh@gmail.com
}

\begin{abstract}
Madura has a variety of cultures, traditions and customs not widely known by the younger generation. Culture and traditions believed hereditary and constitute the identity of the nation must be maintained and conversed by the nation's successor. One of them is Rasolan tradition in Sumber Jerangoh hill, Mandala Village, Rubaru District, Sumenep Regency, Madura Island. Until now, this tradition is still being carried out as a form of gratitude to the one God and Islamic brotherhood because this tradition has made harmony in the life of social structure, especially in Mandala Village. The society of Mandala Village remains enthusiastic in carrying out the Rasolan procession amid the influence of modern culture which has begun to change the mindset of the society of Mandala Village towards culture. Cultures and traditions need to be published widely to society in various ways to conserve regional culture. The Rasolan tradition carried out by the society of Mandala Village, Rubaru district, Sumenep Regency, Madura Island is an annual tradition as a legacy from ancestors. The Rasolan tradition carried out on the hill named "Sumber Jerangoh". Sumber Jerangoh hill is the place where Bhuju' (read: predecessor) societies Burneh Village are, namely Bhuju' Senam and Bhuju' Seloman. Until now, this place is a place which is considered sacred and highly respected by local society. Apart from the tradition of Rasolan as legacy from ancestors that must be carried out, the Burneh society also carries out a ceremony or ritual in the form of Rasolan on the hill of Sumber Jerangoh as a means to remember the services their Bhegatoah/ predecessors who have sacrificed a lot for the development of Burneh village. Therefore, it is considered important that society always pray for and carry out rituals in the implementation of the Rasolan tradition as a reward or fringe benefit to their processors.
\end{abstract}

Keywords: kiai; pesantren; religious; social-politics; change 
JNUS: Journal of Nahdlatul Ulama Studies, Vol. 2, No. 2, Juli 2021: 89-100

\begin{abstract}
Abstrak
Artikel ini memaparkan tentang keberadaan kiai khos, sekelompok elit tradisional baru, yang mampu memainkan peran penting tidak hanya di bidang keagamaan tetapi belakangan ini juga dalam masalah sosial-politik. Peran-peran ini disajikan sebagai manifestasi penguasaan kitab-kitab klasik (kitab kuning) mereka. Sejak KH. Abdurrahman Wahid (Gus Dur) pada masa kepresidenannya, 1999-2001, istilah kiai khos telah menjadi prototipe baru bagi kiai yang tidak hanya memiliki kemampuan agama tetapi juga penguasaan buku klasik. Studi tersebut menunjukkan bahwa elit tradisional baru ini telah mengubah pesantren menjadi dinamis dan mampu mendorong kiai dan santri untuk maju dengan baik dalam konteks politik, ekonomi dan agama. Hal itu dilakukan dengan menggunakan metode etnografi kualitatif dengan pendekatan sosio-antropologis yang menjelaskan ruang baru elit tradisional sebagai hasil artikulasi imajinatif mereka dalam dinamika agama dan politik di Indonesia.
\end{abstract}

Kata Kunci: kiai; pesantren; agama; sosial-politik; perubahan

\title{
INTRODUCTION
}

Indonesia is known for its richness of traditional cultural diversity. One of among the traditional cultures is a traditional ceremony which usually bounded to certain belief or religion, one of the elements of culture that is difficult to change compared to other cultural elements. The traditional ceremony is a form of human effort to seek safety, peace and at the same time maintaining sustainability of life.

Madura has various traditions or rituals that are still preserved until today. The Madurese cultural tradition contains a set of values which basically become a worldview of the Madurese themselves. This culture is transferred in people's lives through traditional ceremonies and serves as a means of communication between fellow citizens. Through various Madurese traditional ceremonies, cultural syncretism is blended with religious teachings, ethical values, and norms that apply in people's lives.

The majority of Madura Island people adhere to the Islamic religion with the ideals of ahlussunnah wal jama'ah ala manhaj Nahdlatul Ulama (NU). Religion is important in their daily life to establish a close relationship in socio-religious behavior. An evidence of strong religious behavior among them is by the existing houses, because almost all houses, 
especially in Sumenep area, have a langgar, while in one village there is at least a public mosque (Huub de Jonge, 1989: 43).

This shows that the people of Madura Island in their daily life cannot be separated from the religious context, so that the religious behavior of the community is not only based on the al-Qur'an and Hadith. However, they are still guided by their ancestral heritage without leaving the prevailing customs and traditions, by carrying out various rituals in strengthening the identity as a traditional Muslim in the village of Mandala in particular and in Indonesian society in general (Siti Maryam, 2012: 7-10).

A strong religious form is also evidenced by the existence of a variety of life and traditions practiced by the NU-affiliated Madura community in general. This can be seen from the symbols used, including sarong and peci (Mochamad Sodik, 2000: 1). The symbolization is demonstrated both as traditional clothes and everyday clothes. So it is not surprising if people wear sarongs and caps (peci) more often, both at religious events and in public places. Sarong and cap are characteristics of the life of the people of Madura Island as well as signifying religious observance.

The Rasolan ceremony which is used as an instrument by the people of Burnih is a form of community service committed to their ancestors. This is an annual activity that is preserved by the community with a variety of events to improve the service of the NU-afiliated people of Burnih to their ancestors.

\section{DISCUSSION}

\section{Theory of Syncretism}

Syncretism comes from English term, which contains the meaning of mixture, combination, and unity. Syncretism is a mixture of two or more traditions that occur in people's lives but in its implementation it does not give rise to clashes and values that occur in life, ritual implementation and so forth. The occurrence of cultural mixture usually involves a change in the traditions carried out by the community. Syncretism here in the article is understood as a mixture of Islamic traditions with elements of local traditions which are usually 
accompanied by series of ceremonies in various forms (Darori Amin, 2000: 83).

The syncretization process between Islam and Java, which took place smoothly, was unified, and total, in the end made Javanese-Islam as if it could not be separated from one another. In fact, if we examine further about Java today, what can be seen is the characteristic of Islam that brings so much influence on it.

The development in the aspects of religion and ritual, IslamicJavanese syncretism is very evident with the amalgamation of religion and local culture. What is meant in the context of combining religion with local culture is implementing Islamic law wrapped by Javanese culture. Thus, the substance of the Sharia that is carried out remains in accordance with the corridors of Islamic teachings, but its outward appearance adopts local traditions (Clifford Geertz, 1981: 318).

\section{The Rasolan Tradition of the Madurese NU Community}

Rasolan tradition is a traditional cultural ceremony in Madura, where traditional ceremonies have been carried out by the people of Dusun Burneh, Mandala, Rubaru, Sumenep, Madura island. The traditional ceremony is usually held in the month of Rasol (bulan rasol) ${ }^{1}$. The traditional Rasolan ceremony took place since most of the people of Dusun Burneh, Mandala village, are traditional farmers. Therefore most of the community is aware that if the harvest is good, there are no pests and so on, then the community will carry out the Rasolan tradition by bringing Rasolan rice (Nasi Rasolan) ${ }^{2}$ and is believed to be a symbol for bengatoah (ancestors) as sign of respect that they have succeeded their harvest ${ }^{3}$, and also for well-being of the people of Dusun Burneh, Mandala village. The Rasolan tradition serves as a mediation in remembering the ancestors and founders of the villages. When there is absence of the Rasolan tradition, it is believed that the village will face

\footnotetext{
${ }^{1}$ Month of Rasol according to Madurese calendary system, or Ba'da Maulud in Javanese calendar, or Rabiul Awwal in Islamic calendar

${ }^{2}$ Nasi Rasolan is a meal made of rice in gunungan shape, with side dishes.

${ }^{3}$ Interview with Ibu Saneye, as the member of Dusun Burneh, Mandala Village in 1 April 2020
} 
a danger or catastrophe for their farm, especially for Dusun Burneh. It is believed that if the community does not remember their ancestors, thus makes the ancestor angry (wrath) and will send a danger to people. People who carry out the Rasolan ceremony are believed to receive blessing in their life for one year. ${ }^{4}$

\section{Elements of Madurese Culture}

During its development, every culture in a society must contain elements that shape its social life, including 1). Religious systems and religious ceremonies. 2). Community systems and organizations. 3). Knowledge system 4). Language. 4). Art 5). Livelihood system. 6). Technology systems and equipment (Fatah Yasin and Famier Liadi, 2007: 10).

Almost every community, religion will always be present and encompass them. So that the presence of religion becomes a color in various religious and cultural ceremonies. Here we are facing a system that was either born from the traditions of the local community or from people who deliberately created it.

The Madurese community has a very complex Islamic teaching system and a community that adheres to the teachings of Islam. And this is proven by the fact that the Madurese people are united by a community, namely langgar. In every village formed by langgar, there must be a mosque. Thus, the mosque and ulama became a symbol of Madurese society today (Huub de Jonge, 1989: 43).

a) Religious systems and religious ceremonies

The Madurese community views that the existence of a religion is a very important element. So that the position of a religious figure becomes part of a rite that they will carry out. In addition, the position of a religious figure in Madurese society is highly respected, both in formal and informal connotations. In terms of structure, figures such as buppa' (father), babu' (mother), guruh (teacher/guardian/kyai), ratoh (king/government) are the order of people of whom we must pay respect. If the father and

${ }^{4}$ Interview with KH. Asmuni, as the elder of Mandala village, 2 April 2020 
mother are people who must be respected personally, then the kyai and the king or the government are people who play an important role in the structure of the society.

b) Community organization system.

Community life is an important structure for the attainment of welfare in Madurese society, generally based on (1) gender differences, (2) age differences, (3) occupational differences, (4) genetic differences, (5) differences in assets owned. (Fatah Yasin and Famier Liadi, 2007:23). So that in social life it is necessary to have shared characteristics in order to achieve a prosperity in life while living in the world.

c) Knowledge system

Talking about the knowledge system for any ethnic group and nation has its own characteristics. This also happened for the Madurese community. Madurese society regards the knowledge of time is very important for them. This is a big consideration in searching for livelihood. Although in general the time has been divided into the same order as modern days, namely MondaySunday. However, the Madurese people divide five days in determining all their activities that resemble Javanese calendar system, namely, (paeng, pon, bagi, kalebun, and manis). As for the division of the months in Madurese society as follows: namely, sorah, sappar, molot, rasol, mandilawal, mandilaher, rejjeb, rebbe, poasa, sabal, makeng / takepek, and reajeh.

d) Language

The language of Madura is basically almost the same as Javanese, which has different levels of status, from these levels the Madurese language is classified according to the levels as follows: (1) Level of crude language, (2) Level of enja'iye language, (3) Level of enggi-enten, (4) Level of enggi-bunten, (5) Level of kraton language.

e) $\operatorname{Art}$

Madurese people in an art space struggle and there are a lot of them, among others. Ludruk, mamaca, tayuban, dances, pencak 
silat, hadrah, samman, samroh, and gambus. In addition, there are many other arts that exist in Madurese society today.

f) Livelihood system

Madura Island, which is located on the east of Java Island, makes Madura an area surrounded by the ocean. However, from some parts of Madura it is considered a barren area, it's just that the daily life of the Madurese community depends on agrarian activities. The Madurese have the following livelihoods: (1) farmers, (2) fishermen, (3) handicraft industry, (4) traders, (5) civil servants, (6) and other occupations (Fatah Yasin and Famier Liadi, 2007: 64).

g) Technology systems and equipment

The technology and equipment systems used by the Madurese community generally depend on the community activities, for example in coastal areas generally using nets, boats, canoes, jukung, etc. These are related to community activities, which are partly fishermen. Whereas for people who farm salt, the equipment they use mostly different.

Basically, the mentioned seven elements make up a community live and survive with all its activities. The Rasolan tradition carried out by community of Dusun Burneh, Mandala, Rubaru, Sumenep, Madura is an annual tradition and a legacy from their predecessors that has been going for years. Until present time, this tradition has reached six generations. The Rasolan tradition is carried out on the hill of Sumber Jerangoh. Sumber Jerangoh hill is the place where the bhuju' (the ancestors) of Dusun Burneh people are, namely bhuju' Sĕnam and bhuju' Sĕloman. Until now, this place is considered sacred and highly respected by the local community.

Like other sacred places, Sumber Jerangoh hill also has a caretaker who until now has reached six generations, namely:

1. The father of Jhu' Asrima

2. Jhu 'Asrima

3. Kĕ Somaeh

4. Morjaki

5. Misnawi, and 


\section{Alghiya}

Those people who are believed to be caretakers are inherited from generation to generation and therefore no one person or society has any objections to it. Another reason why the caretaker is carried out from generation to generation, is because the early foundation of the Rasolan ritual in the month of Rasol was believed by order of the predecessor through repeated dreams for three consecutive nights. The community believes that only the direct descendants of the predecessor can experience this.

Apart from the annual tradition and inheritance of their ancestors that must be carried out, the Dusun Burneh people also carry out ceremonies or rituals in the form of Rasolan on the Sumber Jerangoh hill as a means of remembering the services of their bhengatoah (ancestors) who have sacrificed a lot for the development of Dusun Burneh. This is considered important so that the community always prays as a reciprocal or in return for their services to their ancestors.

\section{Implementation of the Rasolan Tradition among NU-Madura Community}

The Rasolan ritual carried out annually by the Dusun Burneh community in the Sumber Jerangoh hill month on Friday Lĕgi, month Rasol every year. The ritual is carried out right after the Sun rises, around 07.00 until 10.30 AM. When the local community gathered at the hill slope at the given time, the community together climbed the Sumber Jerangoh hill by bringing offerings and dishes for feast after the ritual.

Tahlilan which is performed on the hill is led directly by the caretaker and is the core event of the ritual, it is intended to pray for their predecessors to be accepted by his side. After the Tahlilan ritual is completed, the next session is to enjoy the dishes brought collectively by the local community together. It is intended as a form of gratitude for their sustenance to God by sharing their food with other people who 
also take part in the ritual ceremony. It is a cultural feast among members of community. ${ }^{5}$

After that, the community will gather again to then see the sacred mortar and carry out the replacement of the flag, of course with the permission of the caretaker. In addition to the tomb / bhuju' of ancestors, there are two objects that are considered sacred by the local community, namely lesung (mortar) and tambiuh.

The sacred mortar which is quite large and made of stone located at the top of the hill is believed to shift in position every year, thus believed by the community as a sign and guide to foresee the direction of their life journey for the next year. While the tambiuh filled with water, it is believed to be a sacred place where water cannot be taken. According to the caretaker, if someone uses the water in the tambiuh, it means violation and bad luck will happen to that person. There was a story which is believed by the community that a shepherd once took bath in the sacred tambiuh. Only few days after that, the shepherd turned seriously ill and eventually died, it was believed to be a curse and punishment for his violation. ${ }^{6}$

The replacement of the flag on the tree at the top of the hill is intended as a sign that on this Sumber Jerangoh hill there is a predecessor of the Dusun Burneh community who is highly respected and considered as holy. The replacement of the flag is usually carried out by several people of Burneh community who have specific purposes or wishes for their life. So it is not uncommon attaching more than one flag during the ritual. Even furthermore, the flags are often differed according to the wishes of the person concerned without any mystical things. However, the flag that is taken to be replaced with a new one is usually requested by mystical people, because they think that the flag that is installed for one year on the top of the Sumber Jerangoh hill where the predecessor's tomb is located is sacred. Sometimes people use the flag as charm for them.

\footnotetext{
${ }^{5}$ Interview with $\mathrm{Mr}$. Addur, as the friend of the caretaker, 29 march 2020

${ }^{6}$ Interview with Mr. Surais, as son of the caretaker in Bukit Jerangoh, in 30 March 2020
} 
After those sequences, the Rasolan ritual at Sumber Jerangoh at the top of the hill was completed, and the community descended the hill together after cleaning up the area around the cemetery.

The next session of ritual is a ritual under the Sumber Jerangoh hill. At a time when Islam had not yet fully colored the lives of the Dusun Burneh community, the rituals performed under the hill took the form of a typical Madurese folk song (Këjhung) and a participation of tanda' 'bine' or Madurese typical female dancer whom were usually invited from outside the village. ${ }^{7}$ Before the dancing ritual begins, local people usually play gamble by throwing dice. The dance itself is believed to bring great water from the Jerangoh source, and it is indeed proven, the water that flows from the source after the dance ritual is greater than before. This is increasingly believed to be true by the community when Këjhung and Tanda' Binĕ' are no longer implemented, because society has undergone many changes, especially in terms of knowledge and religion (Helena Bouvier, 2002:334).

In its development, the implementation of the ritual under the hill in the form of a dance was replaced with a religious sermon which was opened with Tahlilan at the mosque which was just below the hill. The incorporation of Tahlilan and religious sermon in the ritual was intended to create a society that has a better personality and religious mentality than before, under context and circumstances of Islamic value. This Tahlilan is held after Friday prayers in congregation. Because of this, until now the water source in Sumber Jerangoh hill has changed into a very small spring compared to previous years, when the community was still performing the dance.

Milton Singer and Robert Redifield developed the twin concepts of Small Tradition and Greater Tradition while studying the orthogenesis of Indian civilization in the city Madras, now known as Chennai. Tradition means passing down information, beliefs and

7 Tanda' Bine' is a sign of a distinctiveness of the Sumenep area and even the island of Madura as a whole. Tanda' Bine' seems to be a typical dance performed by women in Madura. But it is not just any woman: only professional women, and this activity is a rather a specialty for a farming community that does not recognize any conspicuous specialization of activities, especially for women. 
customs by word of mouth by way of example from one generation to another. In other words, tradition is an inherited practices or opinions and conventions related to a social group for a certain period of time. It also includes people's attitudes, long-lasting interactional patterns and socio-cultural institutions.

Great traditions are associated with a few, reflective elites who are able to analyze, interpret, and reflect cultural knowledge. The great tradition is a body of knowledge that serves as a beacon of knowledge. Contrary to this small tradition consists of patterns of beliefs, institutions, knowledge including proverbs, riddles, anecdotes, fairy tales, legends, myths and the whole body of folklore of the people.

In this case, we can see that the Rasolan tradition in Sumber Jerangoh hill is a small tradition which is then mixed, and incorporated with the bigger tradition. At first, this tradition was just merely a ritual with the aim of remembering the predecessors, but the entry of Islam as a major tradition changed the existed ritual of the tradition gradually. One example, as explained above, is that the tradition is marked by Tahlilan and even eliminates the implementation of Këjhung and Tanda' Binĕ' which is actually believed to be a main requirement to make the spring of Jerangoh hill water keep flowing.

\section{CONCLUSION}

Tradition is an ancestral heritage that has been existing and becomes a tradition in people's lives in Indonesia, whose cultural heritage of ancestors are rich. The Rasolan ritual is among richness of tradition Indonesia has. This traditional ceremony inherited from the ancestors of the ancestors has been distorted by many of the successors despite few people are still preserving this tradition.

The discussion above demonstrated that in each of its form, a tradition will more or less experience changes as the result of the subject or actor of the tradition. In the case above, the perpetrators of the Rasolan tradition in the Sumber Jerangoh hill, Dusun Burneh, Mandala village, Rubaru, Sumenep, Madura are religious people adhering Islam as their religion. Their lives which are colored by religious values contained a significant influence, impact, or change on 
the development of the Rasolan tradition that was originated from the local community.

This change occurred, because the community felt that there were rites that were contrary against, or not directly proportional to the teachings of the great tradition (religion) which became their belief at that time. And as long as the perpetrators of tradition/culture preferring and believing in Islam as religion and great traditions, it is difficult to maintain the original traditions of a tribe, including the Rasolan tradition in the Sumber Jerangoh hill, Dusun Burneh.

\section{REFERENCES}

Maryam, Siti. Damai Dalam Budaya: Integritas Tradisi Syi'ah dalam Komunitas Ahlussunnah wal-Jama'ah di Indonesia, Jakarta: BLDKA-RI, 2012.

Amin, Darori. Islam dan Kebudayaan Jawa, Yogyakarta: Gama Media, 2000.

Bouvier, Hĕlĕne. LĔBUR!: Seni Musik dan Pertunjukan dalam Masyarakat Madura, terjemah: Rahayu S. Hidayat dan Jean Couteau, Jakarta: Yayasan Obor Indonesia, 2002.

Fimeir Liadi, dan Moh. Fatah Yasin. Representasi nilai budaya madura dan dayak salam sastra, Jogjakarta: IRCiSoD, 2007.

Geertz, Clifford. Abangan, Santri, Priyayi dalam Masyarakat Jawa, Jakarta: Pustaka Jaya, 1981.

Jonge, Huub de (ed). Agama, Kebudayaan dan Ekonomi, Jakarta: Rajawali Press, 1989.

\section{INTERVIEWS:}

Interview with Ms. Saneye, as the local community of Dusun Burneh, Mandala Village on April 01, 2020.

Interview with $\mathrm{KH}$. Asmuni, as an elder in Mandala Village, on April 02, 2020.

Interview with Mr. Addur, as a relative of the caretaker, on March 29, 2020

Interview with Mr. Sura'is, as the son of the caretaker of Sumber Jerengoh hill, on March 30, 2020. 